\title{
構成モデルで表したセラミックス圧粉体の微細構造と焼結特性
}

\author{
品川一成・平島 康* ・近藤祥人** \\ 阿南工業高等専門学校機峨工学科，774-0017 徳島県阿南市見能林町青木 265 \\ *徳島県立工業技術センター材料技術課，770-8021 徳島市雑賀町西開 11-2 \\ **香川県立工業技術センター材料技術部門, 761-8031 高松市郷東町 587-1
}

\section{Microstructure and Sintering of Ceramic Green Compacts Described in a Constitutive Model}

\author{
Kazunari SHINAGAWA, Yasushi HIRASHIMA* and Yoshihito KONDO** \\ Department of Mechanical Engineering, Anan College of Technology, 265, Aoki, Minobayashi-cho, Anan-shi, Tokushima 774-0017 \\ *Materials Technology Division, Tokushima Prefectural Industrial Technology Center, 11-2, Nisibari, Saiga-cho, Tokushima-shi $770-8021$ \\ ** Material Technology Branch, Kagawa Prefectural Industrial Technology Center, 587-1, Goto-cho, Takamatsu-shi, Kagawa 761-8031
}

\begin{abstract}
The effect of forming pressure on the internal structure and the sintering behavior of green compacts made from ceramic granules was investigated with the aim of describing those by a constitutive model. Alumina granules were compacted by cold isostatic pressing(CIP) at three different pressures of 98,196 and 294 MPa. Examined were the initial pore structure, shrinkage and densification of the granular compacts during sintering at four temperatures in the range between 1100 and $1400^{\circ} \mathrm{C}$. Three distinct regions in the microstructure with fractured, unfractured granules and crack-like cavities were identified as the three peaks observed in the pore size distribution. The ratio of the respective pore volumes in these three regions was independent of the forming pressure within the range under examination, while the pore size decreased as the pressure increased. The sintering rate of the compacts formed at $98 \mathrm{MPa}$ was similar to that at higher pressures, because the dominant process responsible for the densification during sintering is the shrinkage of small pores in a dense region. However, the final density after sintering of the compacts formed at $98 \mathrm{MPa}$ was somewhat lower than that of the compacts formed at higher pressures. This stems from large crack-like pores around the unfractured granules remained even at $1400^{\circ} \mathrm{C}$. The shrinkage behavior was modelled with a set of constitutive equations by taking account of the pore size distribution of granular compacts. The sintering behavior related to the forming pressure could be well described by the present model.
\end{abstract}

[Received June 23, 1999; Accepted November 8, 1999]

Key-words : Alumina, Granules, Compacts, Sintering, Microstructure, Deformation, Constitutive modelling

\section{1. 緒言}

セラミックス粉末の成形では顆粒による乾式成形法が広く用 いられている．この場合，顆粒の破壞の程度が圧粉挙動に影響 するため，顆粒サイズ，水分，温度，スラリ一分散特性等の成 形圧一相対密度関係, 成形体構造への影響について多くの調査 がなされている(1) 10)。また，顆粒境界部分に存在した亀裂は 焼結時に円弧状の大気孔となり，焼結体に残留し，破壊源とな る(1) 13)。 セラミックス製品の普及には破壊強度，信頼性向上 が重要であるため, 顆粒特性の焼結体強度への影響も活発に調 べられている14) 19).これらの結果, 成形圧が高く, 顆粒がつ ぶれやすいほど成形体に残存する粗大気孔の量は少なく，焼結 体の強度も高くなることが分かっている18).

上記の研究は成形体, 焼結体の構造, 欠陥, 強度に着目した ものと言えるが，顆粒に由来する気孔径分布は粗大気孔の生 成, 残留を通して焼結収縮, 緻密化挙動へも影響する20)。一 般的に焼結中の気孔径分布の变化 21 ～24) や不均一構造の焼結举 動の解析例 25$)$ 31) に見られるように, 成形体構造と焼結収縮は 密接な関係にある。近年，ネットシェイプ成形等を目的とした 粉末成形・焼結シミュレーションが注目されているが32)，そ れには焼結収縮挙動を表す構成式が必要である ${ }^{33)}$ 。著者らは 顆粒による成形体については特に不均一組織に対応した構成式 が必要であると考え, 内部構造を考慮した焼結構成モデルの構 築を行った ${ }^{34)}$ 。これにより乾式プレス法に対応した焼結体形 状予測法を示すことができた。しかし，成形王の影響が考慮で きるかについては末だ検討されていない。

ネットシェイプ成形を目的とした焼結体形状の予測では，成
形体の密度分布がその後のマクロな不均一収縮を計算する重要 な因子となる35)。したがって，構成モデルにおいても密度差 を与える成形圧力の影響を表現できなければならない。 なた， 焼結体強度に影響する内部構造のモデルは実際の特徵をよく捉 えていることが望むしい。本研究では成形圧の異なるアルミナ 圧粉体を作製し，内部構造上焼結挙動を調べるとともに，既 報34)で提案した焼結構成モデルを用いてこれらの焼結収縮挙 動の記述を試みる。その際, 成形王が低い場合の緩い拘束を表 せるよう，モデルのより一般的な表現への改良を行う。また， 気孔径分布を計測し, 内部構造モデルとの対応付けを検討する ことにより, 本モデルの物理的意味の明確化も行う。

\section{2. 焼結実験}

\section{1 実験方法}

アルミナ顆粒としてスプレードライ法による市販の顆粒（住 友化学工業, AKS53B) を用いた。一次粒子のBET 径は $0.105 \mu \mathrm{m}$, 顆粒の中心粒径は61 $\mu \mathrm{m}$ である.フローティン グ・ダイで約 $23 \mathrm{MPa}$ で直径 $40 \mathrm{~mm}$, 厚さ $4 \mathrm{~mm}$ 程度の円盤状 試料を圧粉後, $98,196,294 \mathrm{MPa}$ の各圧力で CIP 処理を行っ た。なお，196 MPa は既報34) で用いた条件であるので，本報 ではその前後の王力条件を考察することになる。粉末成形体は $800^{\circ} \mathrm{C}$ で仮焼結してバインダーを除去した後, $100^{\circ} \mathrm{C} / \mathrm{h}$ で昇温

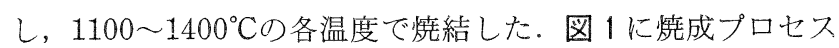
を示す. $800^{\circ} \mathrm{C} て ゙$ 仮焼結した際の試料については水銀ポロシ メーターを用いて気孔径分布を計測した。 その際, 各成形玨に ついて三つのサンプルの測定を行い，その平均を取った。 


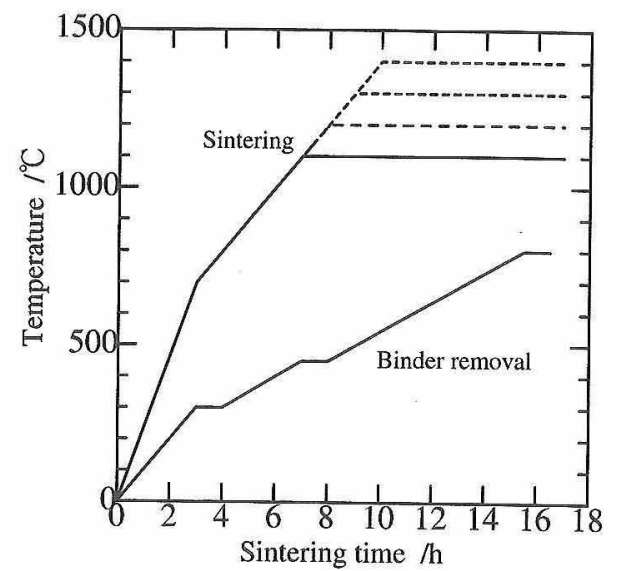

Fig. 1. Firing process.

\section{2 実験結果及び考察}

\section{2 .1 焼結挙動}

図 2 に成形王を变えたときの圧粉体の相対密度の変化を示 す。成形王による初期相対密度の差は $1400^{\circ} \mathrm{C}$ 焼結により若 干縮まるが，最後まで差は残った．図 3 は相対密度一時間曲線 である，成形圧が低下すると初期相効密度が下がるため，焼結 曲線が全体的に下万にシフトしているが，㜔結速度の变化は少 なく，曲線の形はほとんど同じように見える．図４に示すよう に収縮曲線の点から見ると, $1300,1400^{\circ} \mathrm{C}$ 後半を除いて成形

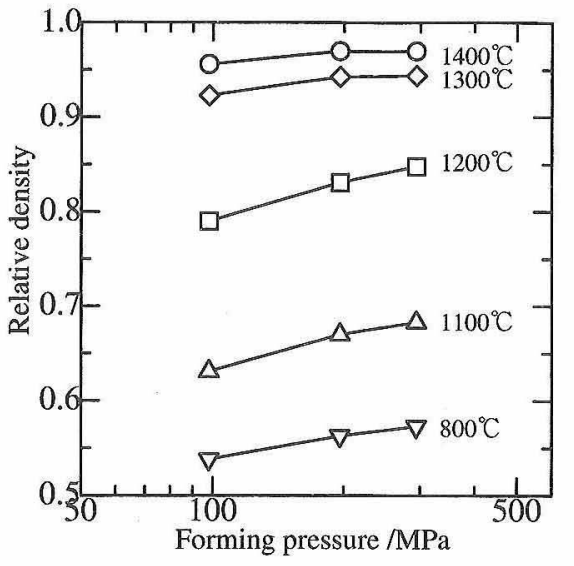

Fig. 2. Change in relative density with forming pressure.

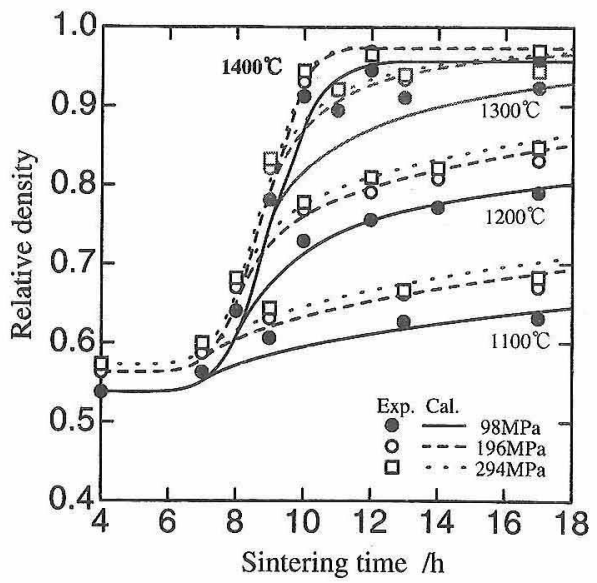

Fig. 3. Relative density-time curve.

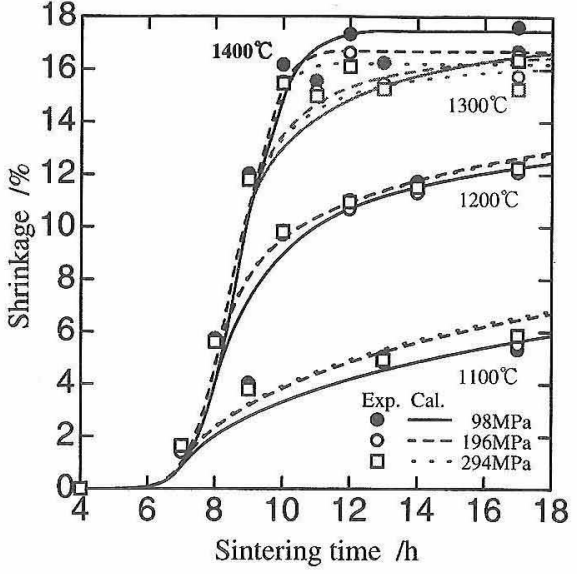

Fig. 4. Shrinkage-time curve.

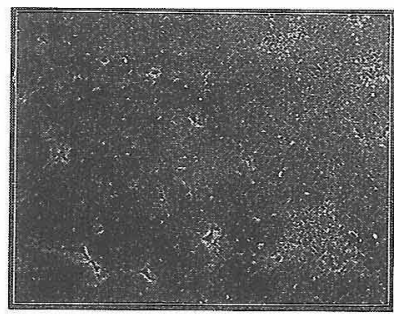

(a) $98 \mathrm{MPa}, 1100^{\circ} \mathrm{C}, 7 \mathrm{~h}$.

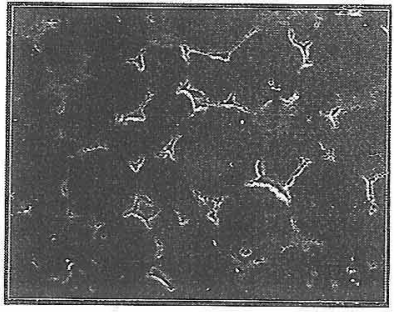

(c) $98 \mathrm{MPa}, 1400^{\circ} \mathrm{C}, 17 \mathrm{~h}$

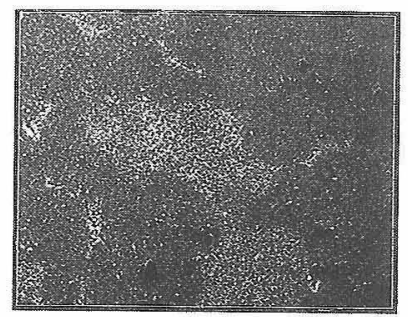

(b) $294 \mathrm{MPa}, 1100^{\circ} \mathrm{C}, 7 \mathrm{~h}$.

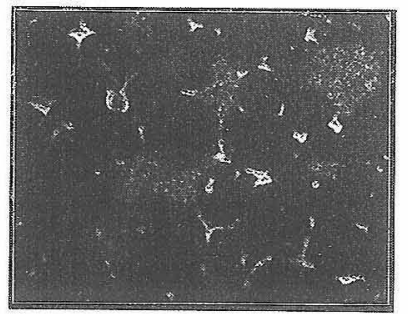

(d) $294 \mathrm{MPa}, 1400^{\circ} \mathrm{C}, 17 \mathrm{~h}$.

\section{$100 \mathrm{um}$}

Fig. 5. Scanning electron micrographs showing microstructure.

圧の影響がほとんど現れていないことが分かる。

図 5 に98 MPa と294 MPa の焼結初期, 後期のミクロ組織 を示す。烍結初期には明瞭でないが，後期には多くのクラック 状気孔が観察される。これらは既報34)で報告したように破填 していない顆粒の周囲に発生するもので, 密な領域と踈な領域 との収縮速度の差から生じたものと考えられる，このクラック 状気孔は低圧で成形した方がより多く残留することが分かる。 このため, 最終的な焼結体密度に成形圧による差異が生じたも のと考えられる，また，成形正が変わっても烤結速度がほぼ同 じであるのは, Zheng と Reed ${ }^{20)}$ が指摘したように大気孔に比 し，密な領域の小気孔の収縮が支配的であるからと考光られ る.

\section{2 .2 成形体構造}

図 6 に $800^{\circ} \mathrm{C}$ の時点で計測した気孔径分布を示す。曲線には 三つの変曲点があり，したがって気孔径に三つのピークがある ことが分かる. 水銀ポロシメーターによる気孔径の絶対値を評 価することは困難であるが，一次粒子と顆粒の寸法差は 2 け ためり，測定結果も小さい側の二つのピークと大きい側の一つ 


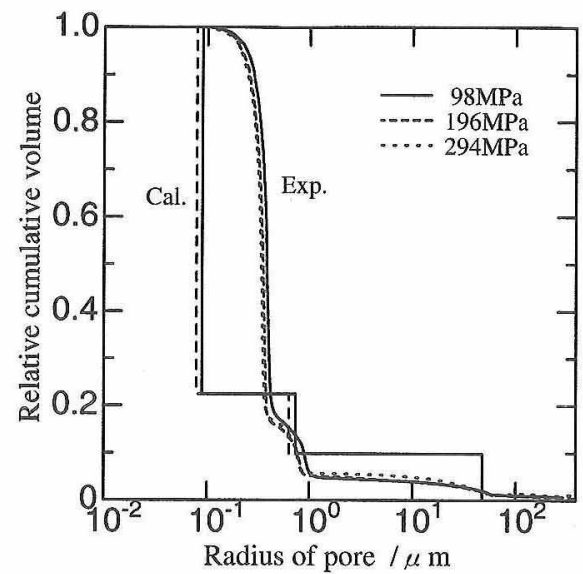

Fig. 6. Distribution of pore size.

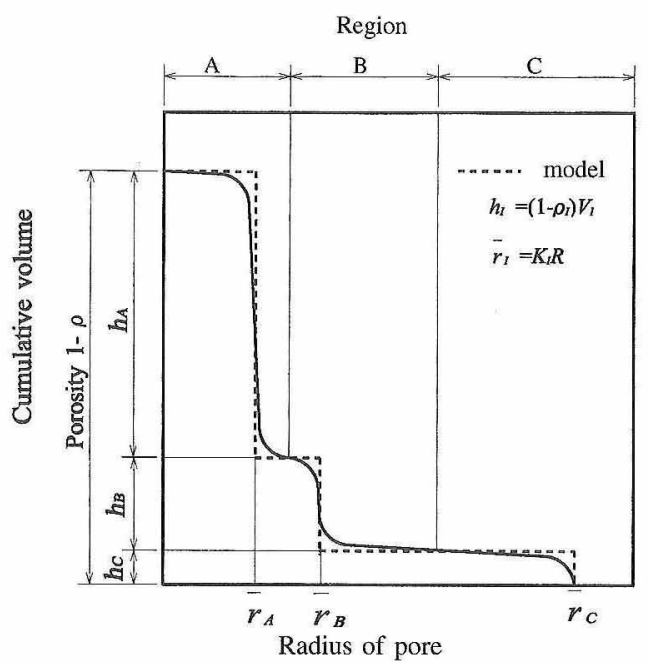

Fig. 7. Schematic representation of relationship between pore size distribution and three region model.

のピークの差が执よそ2けたとなっているのが確認できる。 Kamiya ら²による実験結果と同様, 大きい側のピークは顆粒 周囲の大気孔, 小さい侧の二つのピークはそれぞれ破壊した顆 粒内と破壤しない顆粒内の気孔と考えられる，既報34)で提案
した圧粉体モデルは顆粒が破壊せずに残留した密な領域 $\mathrm{A}$ ， 破壊した疎な領域 $\mathrm{B}$ ，クラック状気孔が生成する領域 C の 3 領域から構成される. 図 7 に気孔径分布と本モデルとの対応を 示す模式図を示す，測定結果における三つのピークは各領域に おける気孔半径の代表值 $\bar{r}$ に相当し, 既報における 3 領域の設 定の妥当性を支持するものと考えられる.

図 6 からは成形王を高くすると領域 $\mathrm{A}, \mathrm{B}$ の二つの気孔半径 $\bar{r}_{\mathrm{A}}, \bar{r}_{\mathrm{B}}$ は小さくなっているのが分かる5),7 . しかし，3 領域の 気孔率の比（図 7 における $h_{\mathrm{A}}: h_{\mathrm{B}}: h_{\mathrm{C}}$ ）に関しては, 調べた 成形王の範囲では変化がなかった，したがって今回の場合，成 形王を96 MPa 以上に増加してもそれ以上破壊する顆粒がな かったと考えられる. その結果, 密な領域 $\mathrm{A}$ と疎な領域 $\mathrm{B} の$ 割合が変わらず，両領域の相対密度が上がり，それぞれ気孔径 が小さくなったものと解勫される。なお，領域 Cの気孔径は 顆粘寸法に依存し，成形王の影響はないと考えられる。

\section{3. 焼結構成モデルによる焼結挙動の計算}

\section{1 䔁成モデルとその改良}

2.2 節で考察した成形体構造と焼結举動の関係を, 構成モデ ルにより表現することを試みる. Shima と Oyane の多孔質体 の構成式 ${ }^{36)}$ を基礎とし，既報34),37)において提案した焼結構成 モデルは次のようになとめられる。

$$
\dot{\varepsilon}_{i j}=\frac{1}{2 \eta_{\mathrm{ABC}}} \frac{1}{\rho^{2 n-1}}\left\{\sigma_{i j}{ }^{\prime}+\delta_{i j} \frac{2}{9 f^{2}}\left(\sigma_{m}+\sigma_{\mathrm{SABC}}\right)\right\}
$$

ここに $f$ は静水圧成分の影響度を表し，

$$
f=1 /(2.5 \sqrt{1-\rho})
$$

で近似でき， $n=2.5$ と仮定される. $\dot{\varepsilon}_{i j}(i, j=x, y, z)$ はひずみ速 度, $\rho$ は相対密度（見掛けの密度と実質部の密度の比）， $\sigma^{\prime}{ }_{i j}$ は 偏差応力， $\delta_{i j}$ はクロネッカーのデルタ， $\sigma_{m}$ は静水圧応力, $\eta_{\mathrm{ABC}}$ は見掛けの粘性係数， $\sigma_{\mathrm{SABC}}$ は有効焼結応力である。ここ で，“見掛けの”粘性係数とは2.2節の特性の異なる各領域 $\mathrm{A}$, B，Cからなる不均一構造を一体 $(A+B+C)$ と見なしたとき の粘性係数を意味し, “有効” 焼結応力上は不均一構造の变化 （クラック生成）への作用を差し引いた全体 $(\mathrm{A}+\mathrm{B}+\mathrm{C})$ の収 縮に奇与する焼結応力であることを意味する。これらは図 8 (a)に示すような2.2節の領域 B 々領域 $(A+C)$ が互いに拘束 し，収縮速度が等しいとした “等ひずみ速度モデル”を仮定す ることによって，それぞれ次式のように導かれた。

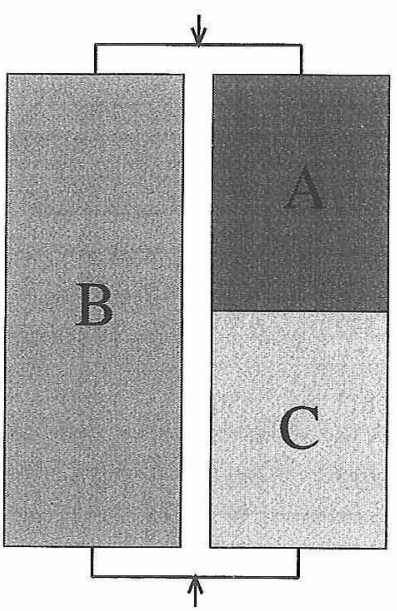

(a)

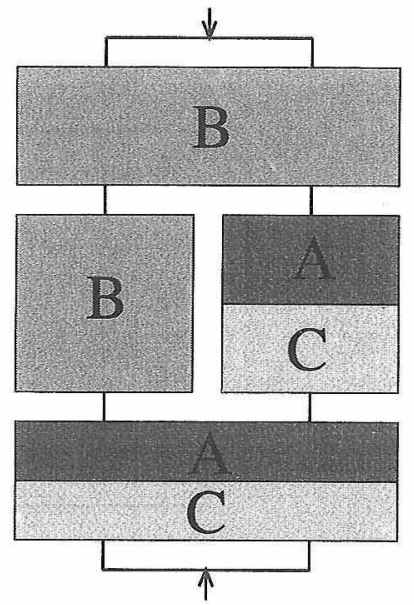

(b)

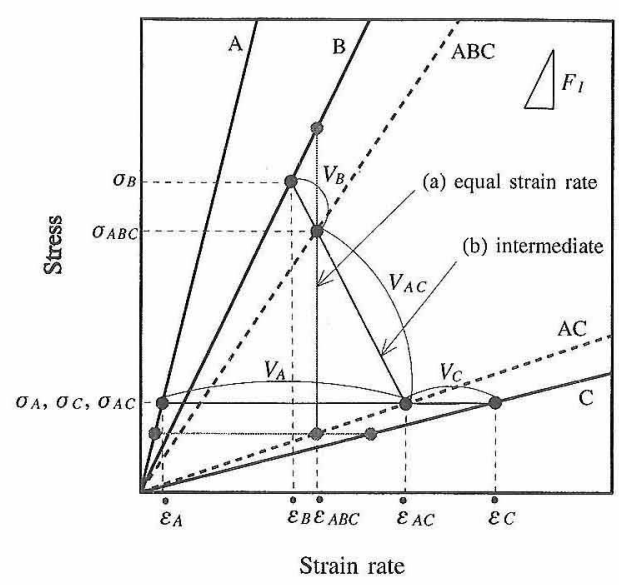

(c)

Fig. 8. Modelling of microstructure.

(a) Equal strain rate model, (b) intermediate model, (c) relationship between hydrostatic part and volumetric strain rate in each region. 


$$
\begin{aligned}
& \eta_{\mathrm{ABC}}=\frac{6.25}{3} \frac{1-\rho}{\rho^{4}} \frac{V_{\mathrm{B}} F_{\mathrm{AC}}+V_{\mathrm{AC}} F_{\mathrm{B}}}{F_{\mathrm{B}} F_{\mathrm{AC}}} \\
& \sigma_{\mathrm{SABC}}=V_{\mathrm{B}} \sigma_{\mathrm{SB}}+\frac{V_{\mathrm{A}} F_{\mathrm{A}}}{F_{\mathrm{AC}}} \sigma_{\mathrm{SA}}+\frac{V_{\mathrm{C}} F_{\mathrm{C}}}{F_{\mathrm{C}}} \sigma_{\mathrm{SC}}
\end{aligned}
$$

ここで, $F_{\mathrm{I}}$ は領域 $\mathrm{I}(\mathrm{I}=A C, A, B, C)$ に招ける静水圧成分上 体積ひずみ速度との比例係数（図 8(c)における傾き）であり， 等ひずみ速度モデル並びに焼結構成モデルの基礎式より

$$
F_{\mathrm{AC}}=\frac{V_{\mathrm{A}} F_{\mathrm{A}}+V_{\mathrm{C}} F_{\mathrm{C}}}{V_{\mathrm{AC}}}, \quad F_{\mathrm{I}}=\frac{6.25}{3} \frac{1}{\eta_{\mathrm{I}}} \frac{1-\rho_{\mathrm{I}}}{\rho_{\mathrm{I}}^{4}}
$$

のように与えられる。 $V_{\mathrm{I}}, \rho_{\mathrm{I}}$ はそれぞれ各領域の体積率 $\left(V_{\mathrm{B}}+\right.$ $\left.V_{\mathrm{AC}}=1\right)$, 相対密度である。 $\sigma_{\mathrm{SI}}$ は各領域の焼結応力39)であり,

$$
\sigma_{\mathrm{SI}}=\frac{2 \gamma}{K_{\mathrm{I}} R} \rho_{\mathrm{I}}^{N}\left\{\frac{\rho_{\mathrm{I}}}{\rho_{0}} \frac{\left(1-\rho_{0}\right)}{\left(1-\rho_{\mathrm{I}}\right)}\right\}^{1 / 3}
$$

ここで, $N=6, \rho_{0}=0.6$ を仮定する。 $K_{\mathrm{I}}$ は気孔の大きさを表す パラメーター, $R$ は粉末粒子半径で, $\gamma$ は表面張力である。 $\gamma$ は本研究ではアルミナの表面張力であり, 次式でその温度依存 性を近似する。

$$
\gamma=\gamma_{0}+\alpha T
$$

$T$ は温度, $\gamma_{0}, \alpha$ は定数である。(5)式における $\eta_{\mathrm{I}}$ は各領域の 粘性係数であり, Coble の粒界拡散モデルより

$$
\eta_{\mathrm{I}}=c_{1} T \exp \left(\frac{c_{2}}{T}\right) d_{\mathrm{I}}^{3}
$$

と表現できる。ここで $d$ は結晶粒径である。結晶粒成長速度 は 2 乗則の粒成長速度式 ${ }^{40)}$ を一般化（ここでは $m+1$ 乗）し， 拡散係数の温度依存性を考慮した次式（微分形）

$$
\dot{d}_{\mathrm{I}}=\frac{c_{3}}{T d_{\mathrm{I}}^{m}} \exp \frac{c_{4}}{T}
$$

で与えられると仮定する ${ }^{38)} \cdot c_{1} \sim c_{4}$ は定数である.

3 領域のモデルは，既報34)では図 8(a)k示す領域 B と領域 $\mathrm{AC}$ が完全に拘束された等ひずみ速度モデルを用いたが，本報 では成形王が低い場合の両領域の緩い結合を表現できるように， 2 相混合組織鋼に対して実用的な簡便法として用いられる友田 ら 41)の“中間型モデル”を適用し，図 8(b)に示すようなひず 及速度差を許す一般的なモデルに拡張する。領域 B と領域 $\mathrm{AC}$ の体積ひずみ速度の比を

$$
\Phi=\dot{\varepsilon}_{\mathrm{B}} / \dot{\varepsilon}_{\mathrm{AC}}
$$

とし全体の体積ひずみ速度は次式で表されると仮定する。

$$
\begin{aligned}
\dot{\varepsilon}_{\mathrm{ABC}} & =V_{\mathrm{B}} \dot{\varepsilon}_{\mathrm{B}}+V_{\mathrm{AC}} \dot{\varepsilon}_{\mathrm{AC}} \\
& =\left(V_{\mathrm{B}}+V_{\mathrm{AC}} / \Phi\right) \dot{\varepsilon}_{\mathrm{B}}=\left(\Phi V_{\mathrm{B}}+V_{\mathrm{AC}}\right) \dot{\varepsilon}_{\mathrm{AC}}
\end{aligned}
$$

3 領域の体積ひずみ速度は既報之同様，

$$
\begin{aligned}
& \dot{\varepsilon}_{\mathrm{A}}=F_{\mathrm{A}} \sigma_{\mathrm{A}}=F_{\mathrm{A}}\left(\sigma_{\mathrm{SA}}+\sigma_{m}-\delta \sigma\right) \\
& \dot{\varepsilon}_{\mathrm{B}}=F_{\mathrm{B}} \sigma_{\mathrm{B}}=F_{\mathrm{B}}\left(\sigma_{\mathrm{SB}}+\sigma_{m}-\frac{V_{\mathrm{AC}}}{V_{\mathrm{B}}} \delta \sigma\right) \\
& \dot{\varepsilon}_{\mathrm{C}}=F_{\mathrm{C}} \sigma_{\mathrm{C}}=F_{\mathrm{C}}\left(\sigma_{\mathrm{SC}}+\sigma_{m}-\delta \sigma\right)
\end{aligned}
$$

で与えられるが，両領域の拘束から生じる内部応力は，

$$
\begin{aligned}
\delta \sigma= & -\frac{V_{\mathrm{B}}}{V_{\mathrm{AC}}} \\
& \times \frac{V_{\mathrm{AC}} F_{\mathrm{B}}\left(\sigma_{\mathrm{SB}}+\sigma_{m}\right)-\Phi\left\{V_{\mathrm{A}} F_{\mathrm{A}}\left(\sigma_{\mathrm{SA}}+\sigma_{m}\right)+V_{\mathrm{C}} F_{\mathrm{C}}\left(\sigma_{\mathrm{SC}}+\sigma_{m}\right)\right\}}{V_{\mathrm{AC}} F_{\mathrm{B}}+\Phi V_{\mathrm{B}} F_{\mathrm{AC}}}
\end{aligned}
$$

のように修正される.同様に(1)式における見掛けの粘性係数 も修正され，

$$
\eta_{\mathrm{ABC}}=\frac{6.25}{3} \frac{1-\rho}{\rho^{4}} \frac{\Phi V_{\mathrm{B}} F_{\mathrm{AC}}+V_{\mathrm{AC}} F_{\mathrm{B}}}{F_{\mathrm{B}} F_{\mathrm{AC}}}
$$

のように与えられる。ここで，(12)式における $\sigma_{I}$ は各領域の 静水王成分であり，本モデルに括ける静水圧成分上体積ひずみ 速度の関係を図8(c)に示す。(11)，(13)，(14) 式に打いて $\phi=1$ の場合 $\left(\dot{\varepsilon}_{\mathrm{B}}=\dot{\varepsilon}_{\mathrm{AC}}\right)$ は既報 34$)$ の等ひずみ速度モデルと一致 する。

\section{2 計算条件}

材料定数は別報38) より表 1 の值を用いる. 焼結初期の結晶 粒径は粉末粒子径 $(2 R=0.105 \mu \mathrm{m})$ と等しいと置く. 各領域 の相対密度 $\rho_{\mathrm{I}}$, 体積率 $V_{\mathrm{I}}$, 気孔の大きさを表すパラメーター $K_{\mathrm{I}}$ ならびにひずみ速度分配比 $\phi$ を表 2 に示す。これらの值は 実験で得られた成形体構造（図 5,6 ）, 焼結挙動（図 3,4）に 関する結果，考察を基に，以下のように決定した。

（1）各領域の初期相対密度 $\rho_{\mathrm{I}}$ は，成形圧の増加上ともにわ ずかに增加する。

（2）成形圧による気孔率 $h_{\mathrm{I}}$ の比の変化はないとし, 既報 ${ }^{34)}$ で沠定した成形圧 $196 \mathrm{MPa}$ の場合についての值 $\left(h_{\mathrm{A}}=0.339\right.$,

\begin{tabular}{|c|c|c|c|c|}
\hline Region & & A & B & C \\
\hline$\eta[\mathrm{MPa}]$ & $\begin{array}{l}C_{1} \\
c_{2}\end{array}$ & & $\begin{array}{l}4.16 \times 10^{13} \\
4.87 \times 10^{4}\end{array}$ & \\
\hline$d[\mathrm{~m}]$ & $\begin{array}{l}c_{3} \\
c_{4} \\
m\end{array}$ & $8.12 \times 10^{-16}$ & $\begin{array}{c}2.08 \times 10^{-16} \\
-4.18 \times 10^{4} \\
3\end{array}$ & $8.12 \times 10^{-16}$ \\
\hline$\gamma[\mathrm{mN} / \mathrm{m}\rceil$ & $\begin{array}{ll}\gamma & 0 \\
\alpha\end{array}$ & & $\begin{array}{l}1117 \\
-0.1\end{array}$ & \\
\hline
\end{tabular}
$\left.h_{\mathrm{B}}=0.055, h_{\mathrm{C}}=0.043\right)$ の比, $h_{\mathrm{A}}: h_{\mathrm{B}}: h_{\mathrm{C}}=0.776: 0.126: 0.098$ を, 成形圧 $98,294 \mathrm{MPa}$ の圧粉体にも用いる。ここで気孔率

\begin{tabular}{|c|c|c|c|c|}
\hline \multicolumn{2}{|c|}{ Pressure (MPa) } & 98 & 196 & 294 \\
\hline \multirow{3}{*}{$\rho$} & A & 0.558 & 0.576 & 0.586 \\
\hline & $\mathrm{B}$ & 0.499 & 0.576 & 0.586 \\
\hline & $\mathrm{C}$ & 0.377 & 0.391 & 0.399 \\
\hline \multirow{3}{*}{$V$} & $\mathrm{~A}$ & 0.811 & 0.800 & 0.800 \\
\hline & B & 0.116 & 0.130 & 0.130 \\
\hline & $\mathrm{C}$ & 0.073 & 0.070 & 0.070 \\
\hline \multirow{3}{*}{$K$} & $\mathrm{~A}$ & 1.7 & 1.5 & 1.5 \\
\hline & $\mathrm{B}$ & 14 & 12 & 12 \\
\hline & $\mathrm{C}$ & 900 & 900 & 900 \\
\hline \multicolumn{2}{|c|}{$\phi$} & 1.23 & 1.00 & 1.00 \\
\hline
\end{tabular}
$h_{\mathrm{I}}$ は, 各領域の体積率, 相対密度から次のように計算される。

$$
h_{\mathrm{I}}=\left(1-\rho_{\mathrm{I}}\right) V_{\mathrm{I}}
$$

各領域の体積率 $V_{\mathrm{I}}$ は，この式より逆算して決定される。

（3）気孔の大きさを表すパラメーター $K_{\mathrm{A}}, K_{\mathrm{B}}$ は， 196, $294 \mathrm{MPa}$ の王粉体については既報 ${ }^{34)}$ の值を用い, $98 \mathrm{MPa}$ の み大きな值を採用する。なお， $K_{\mathrm{C}}$ の值については既報のよう に 90 以上を与えれば，モデル上，収縮力のないクラック領域 としての特性を表すのに十分であるが，今回は実験值に合うよ うに900と置き直す。なた， $K_{\mathrm{C}}$ には成形圧による差は与えな い.

（4）ひずみ速度分配比 $\phi は 196,294 \mathrm{MPa}$ については1（等

Table 1. Material Constants

Table 2. Parameters for Each Region 


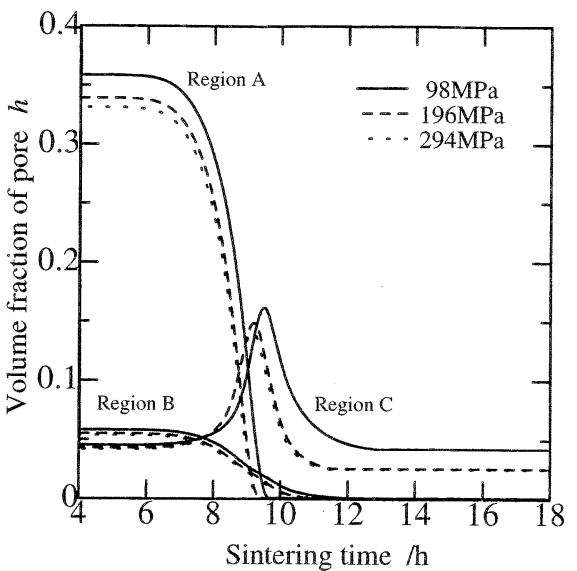

Fig. 9. Variation of porosity in three regions $\left(1400^{\circ} \mathrm{C}\right)$.

ひずみ）とし，成形圧の低い $98 \mathrm{MPa}$ の場合は 1 以上の值を採 用する。これは領域 B と領域 $\mathrm{AC}$ の拘束が緩く, 上り領域 C の拡大(クラック状気孔の発達）が起こりやすいことに相当す る.

これらの具体的な数值は実験結果にフィットするように決定し た.

なお，対象としているプロセスは図 1 のように昇温過程を 含んでいるが，既報と同様に昇温過程は階段状の等温焼結の集 合で近似する手法42)により対処する。

\section{3 計算結果及び考察}

$$
\begin{gathered}
\text { 本モデルにおける各領域の気孔半径の代表値は } \\
\bar{\gamma}_{\mathrm{I}}=K_{\mathrm{I}} R
\end{gathered}
$$

で表される。この值と気孔率 $h_{\mathrm{I}}$ との関係，すなわち本モデル における初期気孔径分布を図 6 に示す。実験值は測定法に依 存する值であるため, 図 7 の模式図のように計算結果の一致 を見ることはできないが，測定された気孔径分布の特徵をよく 表している。この成形体構造を基にした相対密度, 収縮率一時 間曲線の計算結果をそれぞれ図 3,4 に示す。これより本モデ ルが成形圧の異なる圧粉体の焼結挙動をよく表すことができて いることが分かる。焼結による気孔率 $h_{\mathrm{I}}$ の変化を計算した結 果を図 9 (焼結温度 $1400^{\circ} \mathrm{C}$ ) に示す。領域 C の気孔率の増加は クラック状気孔の発達に相当する。成形圧の低い場合は気孔の 残留量が多くなるように計算されており，図 5 に示した観察 結果とも傾向は一致している。

\section{4. 結 言}

成形王の異なる圧粉体を焼結し, 気孔径分布, 焼結挙動を調 ベた，また，既報で提案した焼結構成モデルに更にひずみ速度 分配パラメーターを考慮することにより，より一般的に焼結挙 動を表すことができた。また，本モデルにおける気孔径分布と 実際の気孔径分布の特徴を合致させることができ，モデルの物 理的意味合いを示すことができた。

今後, 成形王, 顆粒強度等の成形過程におけるプロセス，材 料パラメーターと本焼結構成モデルにおけるパラメーターの関 係を定量化できれば，成形一焼結過程の一貫したシミュレー ションが可能になると考えられる。

\section{文献}

1) S. J. Lukasiewicz and J. S. Reed, Am. Ceram. Soc. Bull., 57, 798-801 (1978).
2) J. A. Brewer, R. H. Moore and J. S. Reed, Am. Ceram. Soc. Bull., 60, 212-15 (1981).

3) R. A. Youshaw and J. W. Halloran, Am. Ceram. Soc. Bull., 61, 227-30 (1982).

4) R. A. DiMilia and J. S. Reed, Am. Ceram. Soc. Bull., 62, 48488 (1983).

5) R. G. Frey and J. W. Halloran, J. Am. Ceram. Soc., 67, 199203 (1984)

6) D. W. Whitman, D. I. Cumbers and X. K. Wu, Am. Ceram Soc. Bull., 74, 76-79 (1995).

7) H. Kamiya, K. Isomura, G. Jimbo and J. Tsubaki, J. Am. Ceram. Soc., 78, 49-57 (1995).

8) N. Miyata, Y. Ishida, T. Shiogai and Y. Matsuo, J. Ceram. Soc. Japan, 103, 1275-81 (1995).

9) H. Takahashi, N. Shinohara and K. Uematsu, J. Ceram. Soc. Japan, 104, 59-62 (1996).

10) Y. Okumoto, K. Atagi, Y. Kondo and K. Ishizaki, J. Ceram. Soc. Japan, 105, 771-74 (1997).

11) K. Uematsu, M. Miyashita, J.-Y. Kim, Z. Kato and N. Uchida, J. Am. Ceram. Soc., 74, 2170-74 (1992).

12) K. Uematsu, M. Miyashita, J.-Y. Kim and N. Uchida, J. Am Ceram. Soc., 75, 1016-18 (1992)

13) M. Miyashita, J.-Y. Kim, Z. Kato, N. Uchida and K. Uematsu, J. Ceram. Soc. Japan, 100, 1357-60 (1992) [in Japanese].

14) B. D. Mosser, J. S. Reed and J. R. Varner, Am. Ceram. Soc. Bull., 71, 105-09 (1992).

15) H. Tanaka, A. Sakamoto, Y. Nagao, S. Fukai, Y. Zhang, N. Uchida and K. Uematsu, J. Ceram. Soc. Japan, 102, 397-400 (1994).

16) H. Tanaka, A. Sakamoto, Y. Nagao, S. Fukai, Y. Zhang, N. Uchida and K. Uematsu, J. Ceram. Soc. Japan, 102, 1075-78 (1994).

17) H. Tanaka, A. Sakamoto, Y. Nagao, S. Fukai, N. Uchida and K. Uematsu, J. Am. Ceram. Soc., 77, 3077-80 (1994).

18) Y. Kondo, Y. Hashizuka, M. Nakahara and K. Yokota, J. Ceram. Soc. Japan, 103, 1037-40 (1995).

19) Y. Okumoto, K. Atagi, Y. Kondo and K. Ishizaki, ATM, 1 , 101-07 (1998)

20) J. Zheng and J. S. Reed, J. Am. Ceram. Soc., 72, 810-17 (1989).

21) M.D. Sacks and T.-Y. Tseng, J. Am. Ceram. Soc., 67, 532-37 (1984).

22) A. Roosen and H. K. Bowen, J. Am. Ceram. Soc., 71, 970-77 (1988).

23) S. Taruta, K. Okada and N. Otsuka, J. Ceram. Soc. Japan (Seramikkusu Ronbunshi), 98, 29-35 (1990) [in Japanese].

24) H. Kamiya, K. Isomura, G. Jimbo, T. Hotta and J. Tsubaki, J. Ceram. Soc. Japan, 101, 285-90 (1993).

25) A. G. Evans, J. Am. Ceram. Soc., 65, 497-501 (1982).

26) G. W. Scherer, J. Am. Ceram. Soc., 67, 709-15 (1984).

27) R. Raj and R. K. Bordia, Acta Metall., 32, 1003-19 (1984).

28) C. H. Hsueh, A. G. Evans, R. M. Cannon and R. J. Brook, Acta. Metall., 34, 927-36 (1986).

29) G. W. Scherer, J. Am. Ceram. Soc., 70, 719-25 (1987)

30) R. K. Bordia and G. W. Scherer, Acta Metall., 36, 2411-16 (1988).

31) C.-H. Hsueh, A. G. Evans and R. M. McMeeking, J. Am. Ceram. Soc., 69, C64-66 (1986).

32) S. Shima, J. Japan. Soc. Tech. Plasticity, 37, 177-82 (1996) [in Japanese].

33) K. Shinagawa, J. Japan Soc. Tech. Plasticity, 38, 956-61 (1997) [in Japanese].

34) K. Shinagawa and H. Hirashima, JSME Int. J., Series A, 42, 17-24 (1999)

35) K. Mori, K. Osakada, T. Yoneda and T. Hirano, J. Japan Soc. Tech. Plasticity, 32, 1136-41 (1991) [in Japanese].

36) S. Shima and M. Oyane, Int. J. Mech. Sci., 18, 285-91 (1976).

37) K. Shinagawa, JSME Int. J., Series A, 39, 565-72 (1996).

38) K. Shinagawa and Y. Hirashima, Metals and Materials, 4, 350-53 (1998)

39) K. Shinagawa, Comput. Mater. Sci., 13, 276-85 (1999).

40) For example H. Matsubara, Ceramics Japan, 30, 385-94 (1995).

41) Y. Tomota, K. Kuroki and I. Tamura, J. Iron Steel Inst. Japan, 61, 107-18 (1975) [in Japanese].

42) For example, JSME, "Thermomechanical Behavior of Materials during Transformation," Corona (1991) p. 46 [in Japanese]. 例えば, 日本機械学会編, “相变態と材料挙動の数值シミュ レーション”，コロナ社 (1991) p. 46 